\title{
Deconstruction: A Cornucopia of Esoteric Meanings
}

\author{
Myson Karim Ibrahim Alqudah
}

\author{
Arabic Department- Mutah University - Jordan
}

\begin{abstract}
This paper sets out to explore Deconstruction with view at clarifying its role in the field of literary criticism. As such, the paper traces the philosophical roots of deconstruction in the works of Frederick Nietzsche up to Jacque Derrida, among other contributors. The paper also dwells on the mechanism of deconstructive reading of text, especially its deviation from the structuralist approach. A particular emphasis is placed on the employment of deconstruction in the feminist canon, through paying attention to the deconstructive feminist views of notable feminist critics like Helen Cixous, Luce Irigary, among others. Finally, the paper surveys some of the critique made against the deconstructive approach and the defence made in return. Keywords-Critical Theory, Feminist Deconstruction, Literary Criticism Literary Deconstruction, Philosophical Deconstruction.
\end{abstract}

\section{INTRODUCTION}

Deconstruction is basically a theory about language and literature that developed in the 1970s. It is the most significant of all poststructuralist developments in literary critical thought. Deconstruction subscribes to the poststructuralist view of language in which signifiers do not give rise to definite signified but rather result in new signifiers. As one critic put it "for poststructuralists and for Deconstructionists texts do not say "A" and not "B", but rather "A" and not "A" "(Latimer 249).

It was Frederick Neitzche who radically questioned the validity of basic philosophical concepts such as "knowledge" and "truth". Neitzche undermined the idea that truth is a spiritual quality that rises above language. He saw all the Western ideals as a projection of power, a will to establish a defined truth that is originally in flux and has no stable identity (Ryan 69).

Deconstruction was actually a reaction against the primacy of structuralism in literary criticism. It launched a poignant attack against many of the ironclad assumptions held by structuralism and promulgated a wholesale rejection of them. Deconstruction denies the existence of order and meaning in the text. Actually as its name implies, Deconstruction finds disorder and a constant tendency of the language to deconstruct its apparent sense.

\section{DISCUSSION}

Like structuralism, Deconstruction recognises the textual significance of the text. However, it concentrates on the rhetorical rather than the grammatical aspect of the text. As one critic observed, for Deconstruction the contest between the grammatical and the rhetorical is inherent in language. Grammar is the syntagmatic meaning, meaning as created by placement. Rhetoric is the intertextual system of signs which makes what the grammar means mean something else. Irony and metaphor are principal examples on the rhetoric (Guerin et.al 254).

The structuralists claim that there is a kinship between meaning and structuralist theory itself. However, since there is no possibility of absolute truth, Deconstruction seeks to undermine this pretence. Deconstruction declines the fact that the textual meaning is authenticated with a certain methodological discipline. In Deconstruction, knowledge is viewed as embedded in the text, not authenticated with a certain literary approach (Guerin et.al 257).

One of the poignant attacks launched against structuralism is that it is a- historical. Deconstruction argues that life and thought are historical; they change different relations with different elements at different times. In addition, Deconstruction declines the structuralist as sumption that there are universal structural principles of meanings that exist before language. Structures are historical, temporary, contingent, operating through differentiation and displacement (Latimer 256).

The structuralists view meaning as a matter of difference. The sign "boat" gives us the signified boat because it is different from "moat" "goat" "coat"...etc. Deconstruction argues that if the meaning of the sign is a matter of what it is not, its meaning is in a sense absent from it. If the meaning of the sign "boat" is recognised because it is not "moat "or "coat", one does not know where to stop. Accordingly, Deconstruction believes that there is no distinction between the signifier and the signified. The meaning of a signified in a dictionary may yield another signifier and so on. In this sense if structuralism derives the signified from the signifier, Deconstruction derives the signifier from the signified (Eagleton 127-129). 


\section{LITERARY DECONSTRUCTION}

The original premises of Deconstruction were first formulated by the French philosopher Jacques Derrida. Derrida's books, including Speech and Phenomena, Writing and Difference and Of Grammatology made the major turn in the evolution of Deconstruction. They were important to deconstructionists like Harold Bloom, Hillis Miller, and Barbara Johnson.

Derrida's most influential term is "difference." The Deconstructionists believe that difference pre-exists being as a trace comes before the presence of a thing. Similarly, writing, which is for Derrida another name for difference precedes speech. For Derrida a system of difference precedes any location of meaning in the text. As Jonathan Culler notes, Deconstruction looks for any thing in the text that counters an authoritative interpretation, including interpretations that the work itself appears to encourage (Rivkin and Ryan 341)

The Derridean concept of difference links up with the Freudian and Marxist ideas. Freud and Marx highlight the concepts of displacement and substitution. What is meant is different from what appears to be meant. All texts are recognized through their difference from other texts, and therefore similar to them. Any text includes that which it excludes, and exists in its difference from or affiliation with other texts. This does not mean that there is no meaning. Rather it means that what we take to be a meaning is textually modulated in an interweaving play of texts. This meaning draws on affiliations that are historical in some sense.

Derrida's Deconstruction attacks what he calls "logocentrism." Logocentrism is belief in some ultimate essence or truth that acts as the foundation of all thoughts and beliefs. Under the umbrella of logocentrism is the term " Transcendental Signifier." This term indicates "the sign which will give meaning to all other signs". Equally important is the "Transcendental Signified" which denotes "the unquestionable meaning to which all signs can be seen to point, such as "God"," idea", “ meaning".... etc"(Eagleton 131).

Derrida finds logocentrism depends on a framework of two- term oppositions such as being/ nonbeing, male /female and presence/ absence. In the logocentric system, the first term of each pair is the stronger. Derrida is critical of these hierarchical polarities, and seeks to reverse the order of each pair. This comes through putting them in a slightly different position within a word group, or by substituting words in other languages that look and sound alike.

This attack against logocentrism springs from the deconstructionist's belief that any transcendental meaning is a fiction. There is no concept that is not prone to open-ended play of signification. As Terry Eagleton says, logos are actually elevated by social ideologies. These logos speak not only truth, but also authority (Egleton 131).

Derrida believes that all meaning is textual and intertextual. There is nothing outside the text. Every text exists only in relation to other texts through affiliation, allusion, and repetition. This does not mean that there is nothing outside of language. Intertextuality refers to the realm of human knowledge, not to the realm of concrete existence. Deconstruction does not deny the existence of an independent, physical world.

Deconstruction views literature as an institution, brought into being by the legal, social and political processes. In spite of the diversity in the deconstructive mood, there is for most deconstructionists a general way of approaching the literary text. Reading literary texts in a deconstructive mode is not a matter of decoding the meaning, it is a matter of entering into the constant play of contradictions.

Culler says that the practical strategy of deconstructive reading is to work on the fissures, reversals, oppositions and exclusions. The text is examined for ways in which it suggests a difference from itself, interpretations that undermine the apparently primary interpretation. To achieve this end, deconstrucion focuses on the marginal and the supplementary. Actually, in Deconstruction, the margin can be read as the centre of the text (Latimer 260-261).

As Raman Selden observes, the deconstructionist begins by disclosing the hierarchical order of the text, such as the pair of terms soul/body, and masculine/feminine. The deconstructionist aims at reversing this hierarchy by discerning a chink in the symmetry that allows this reversal. However this newly asserted hierarchy is not allowed to install another truth, and that is why indeterminacy prevails (89).

The deconstructive method of reading marks a radical departure from the traditional formalist criticism. Formalist criticism is based on the belief that a careful study of a text will yield the meaning of the work. For Deconstruction, the possibility of the production of meaning is limitless, for no one meaning exists, but rather a cornucopia of esoteric meanings are embedded within the texture of the text. Just as the consideration of one signifier leads to the production of more signifiers, the consideration of one meaning in the text leads to other possible meanings.

Accordingly, It is a common misconception that deconstructing a text means taking it apart and showing its limitations. Actually, in the activity of Deconstruction, one is not dismantling the text, but rather is showing the 
means by which the text has already dismantled itself. A deconstructive reading aims to illustrate that the conflicting forces within a text undermine the apparent definiteness of its meaning.

The most important school of Anglo-American Deconstruction is the Yale School of Deconstruction. Actually, the Yale School was the original name of Deconstruction. It included critics like Hillis Miller, Geoffrey Hartman and Harold Bloom. However, the most influential critic was Paul de Man.

All language for de Man is inherently metaphorical. Philosophy, law and politics employ metaphors just as fiction does. The only difference is that literary works acknowledge their metaphorical status, whereas the other genres pass themselves off as ineluctable truth. De Man's pivotal belief was that literary language subverts its own meaning. That is why he saw that literature does not have to be deconstructed; it can be shown to deconstruct itself (145).

\section{FEMINIST DECONSTRUCTION}

As a system that undermines binary oppositions, Deconstruction has been adopted by feminism. Extending the work of Derrida, feminist critics have deconstructed the phallocentric pair male/female. They view phallocentrism as an offshoot of logocentrism, and they combine them in the term "phallogocentrism". Deconstructive feminists have attacked the patriarchal society that has given women secondary sexual, economic, and social roles.

In this aspect, Helen Cixous and Lewis Irigaary deploy a deconstructive approach in the question of feminism and gender identity. They argue that the oppositions of the patriarchal culture have linked men with truth and reason, while women have been associated with falsity and irrationality. Irigary argues that women should escape these oppositions and locate their own identities, while Cixous calls for developing a mood of writing which will transcend all these oppositions. She calls this mood "feminine writing" (Ryan 75).

In her This Sex Which Is Not One Irigary elaborates deconstructive theory of feminist separatism. Women have been portrayed as body, physicality or irrationality, and thus as the opposite of all positive values in society. Irigary argues for decanonising this opposition. She proposes that women step outside the system of male hegemony. They must fall back on themselves and value their own bodies instead of despising them as the male tradition has argued (Irigary 178 - 185).

Moreover, Helen Cixous, in her The Newly Born Woman offers a similar argument. Women must abandon the male phallocentric tradition of the opposition between active and passive, nature and culture and man and woman. They must write the transverse tradition that underlies all of these oppositions. She argues that only through the ecritice feminine or feminine writing can women achieve this end (Cixous and Clement 246- 251).

Julia Kristeva has used the work of Freud to launch one of the most daring theories in this aspect. What Kristeva does is to rewrite the Lacanian theory of the Symbolic Order. She opposes to the symbolic what she calls the "semiotic." This term indicates "a pattern or play of forces which we can detect inside language." The semiotic is the other of the language. It is associated with femininity whereas the symbolic is a form of writing that is associated with the "Law of the father." However the semiotic is not a language exclusive for women. It arises from the pre-Oedipal period which recognises no distinctions of gender and so it might be called as a "a bis exual form of writing."

Kristeva views the semiotic as a means of decanonizing the symbolic order. The semiotic is opposed to all transcendental signifiers in the phallogocentric society. It destroys and negates the signs of this order. It disrupts the secure meaning of the ordinary language and splits apart the socially accepted values. Most importantly, and as a bisexual form of writing, the semiotic undermines the distinction between the masculine and the feminine, and then deconstructs all the binary oppositions connected with this distinction like male/ female, and authority/ obedience (Eagleton 187189).

\section{CRITQUE OF DECONSTRUCTION}

Deconstruction has been the object of attack of many critics. Deconstruction has been attacked not only because of its denial of meaning to any work of literature or any literary approach, but also because of its set of descriptive terms which describe the inimical relationship between the reader and the text. Examples on Deconstruction's neologism include terms like "self destruction", "overturning", "attacking" or "undermining" of texts.

The major attack on Deconstruction has been because of its lack of seriousness bout reading literature. Critics of Deconstruction pointed out that it reads all works of literature in a similar way. In this sense it makes its readers start with a set of conclusions and forces them to arrive at the same point lacking any kind of suspense during reading. In addition, those critics feel that Deconstruction is responsible for the heavy emphas is on theoretical rather than practical criticism in recent years (Guerin et. al 258). All of these defects in Deconstruction allowed some critics to describe Deconstruction as nonhuman. 
However proponents of Deconstruction have pointed out that it is intrinsically and deeply human. The most compelling evidence on this is that it is affirmative of the paradoxes and multiplicity of our life as signifying beings. If Deconstruction opposes humanism, it is because Deconstruction wants to clarify the instability upon which such a concept is grounded. (Latimer 299).

The most trenchant attack comes from the critic Jurgan Habermas. In his The philosophical Discourse of Modernity, Habermas takes a very strong case against Deconstruction. He views that Deconstruction tends to collapse all genre distinction, especially that between literature and philosophy. He says that the main fault of Derrida's work is that he links literature with philosophy and that he treats them as purely rhetorical constructs (Norris 49-53).

However, Derrida rejects the distinction between the literary and the non-literary. $\mathrm{He}$ argues that Deconstruction is not a literary theory per se. Rather it is a theory of reading. For Derrida there is always a flickering and diffusing of meaning in the text. This " aporia of meaning" is evident in all writings. Therefore, a deconstructive reading might be applied to any text. The more universal the text, the more powerfully it can provoke deconstructive reading.

Accordingly, Habermas was mistaken in condemning Deconstruction because it groups philosophy with other kinds of writing. It is true that Derrida considers philosophy as a certain "kind of writing". However, what Derrida does is not giving us philosophy undermined at the hand of literature but a literature that is a challenge for philosophy in every aspect of its argument. Actually, as one critic put it, it is the sense of pursuing the play of meaning in the text and not attending to certain author or discipline that makes Deconstruction an attractive literary theory. That is why Deconstruction has been the leading literary theory over the last twenty years (Guerin et. al 258).

A final word concerning Deconstruction is the remark of a commentator who pointed out that

"Deconstruction is not a technique or a method, and hence there is no question of applying it. It is a moment of deepest concern with limits. It is not a hymn of indeterminacy or a life imprisonment within language or a denial of history. Context and historicity are among the most emphasised topics in Derrida's writings. The ethical and the political are not avoided by Deconstruction but are implicated at every step" (Latimer 277).

\section{REFERENCES}

[1] Cixous, Helene and Catherine Clement. The Newly Born Woman. Trans. Betsy Wing. Intro. by Sandra M .Gilbret. Minneapolis: U of Minnesotta P, 1986.

[2] Eagleton, Terry. Literary Theory: An Introduction. Blackwell, 1996.

[3] Guerin, et.al. A Handbook of Critical Approaches to Literature. 3rd ed. Oxford University Press, 1992.

[4] Irigary, Luce. This Sex Which Is Not One. Trans. Catherine Porter and Carolyn Burly. New York: Cornell University Press, 1985.

[5] Latimer, Dan. Contemporary Critical Theory. San Diego: Harcourt, 1989.

[6] Norris, Christopher. "Deconstruction, Postmodernism and Philosophy: Hebermas on Derrida." What's Wrong With Postmodernism: Critical theory and the ends of philosophy. BPCC Great Britain, 1990 (49-67).

[7] Rivkin, Julie and Michael Ryan. "Introduction: "The Class of 1968- Post-structuralism par lui- meme." " Literary Theory: An Anthology. Blackwell Publishers, 2000 (333-357).

[8] Ryan, Michael. Literary Theory: A Practical Introduction. Blackwell Publishers Ltd., Oxford, 1999.

[9] Selden, Raman. Practicing Theory and Reading Literature: An Introduction. Prentice Hall, 1989. 